\title{
CORRIGENDUM
}

\section{SIMPLE CONTINUITY INEQUALITIES FOR RUIN PROBABILITY IN THE CLASSICAL RISK MODEL-CORRIGENDUM}

BY

\author{
Evgueni GordienKo AND PATRicia VÁZQUEZ-ORTEGA
}

Doi: 10.1017/asb.2016.10. Published by Cambridge University Press, 2016.

In Gordienko and Vázquez-Ortega (2016) page 801, the following reference was listed incorrectly: Yu, M.A. (2005) Sensitivity and convergence of uniformly ergodic Markov chains. Journal of Applied Probabilities, 42, 1003-1014. It should have instead been listed as: Mitrophanov, A. Yu. (2005) Sensitivity and convergence of uniformly ergodic Markov chains. Journal of Applied Probability, 42, 1003-1014.

We sincerely regret the error and any problems that have resulted for the authors and readers.

\section{REFERENCE}

Gordienko, E. and VÁzquez-Ortega, P. (2016) Simple Continuity Inequalities for Ruin Probability in the Classical Risk Model. ASTIN Bulletin, 46(3), 801-814. 